\title{
Study of wind power utilization in district heating systems in the Westfjords, Iceland
}

\author{
Kamil Mathews, Anna Sowiżdżał \\ AGH University of Science and Technology, Faculty of Geology, Geophysics and Environmental Protection, Department of \\ Fossil Fuels; al. A. Mickiewicza 30,30-059 Krakow, Poland; e-mail: kamil.mathews@gmail.com, ansow@agh.edu.pl \\ (c) 2019 Authors. This is an open access publication, which can be used, distributed and reproduced in any medium according \\ to the Creative Commons CC-BY 4.0 License requiring that the original work has been properly cited.
}

Received: 12 October 2018; accepted: 12 March 2019; first published online 16 May 2019:

\begin{abstract}
Some Renewable Energy Sources (RES), such as wind power, are often regarded as intermittent. That means they are not available on demand, but rather depend on external conditions e.g. such as the weather. In order to manage these resources, it is advised to combine them with energy storage or other energy sectors, what is known as "sector coupling". This approach is set to mitigate the negative impact of unstable renewable energy sources and manage the generated surpluses. In this study, a system combining wind turbines, district heating network and short-term thermal energy storage was proposed and examined for the instance of the Westfjords, Iceland. Ísafjörður, Patreksfjörður, Bolungarvík and Flateyri are the exemplary communities with existing district heating networks, chosen to investigate the implementation of the system. A short review of the current state of the energy sector in Iceland was provided to present the local conditions. Wind potential in the described area was estimated as high in comparison with average wind turbine generation in the European Union and a few instances of wind turbines placement were analyzed in this study. For locations close to the district heating network, a long-term correlation between power generation and usage was proven. However, locating wind turbines in places with better wind conditions, provides stable output and a similar amount of energy produced by fewer generators.
\end{abstract}

Keywords: Renewable Energy Sources, sector coupling, wind turbines, district heating, Thermal Energy Storage, Iceland, the Westfjords

\section{INTRODUCTION}

Apart from the numerous benefits of renewable energy sources (RES), there are some disadvantages of utilizing those technologies. Relatively high capital investment costs (Ellabban et al. 2014), low predictability (Rahbar et al. 2015, Shen \& Ritter 2016) and power generation intermittency (Turkenburg et al. 2000) are commonly raised issues. Wind is volatile in its nature and its almost zero marginal costs must be offset by the fact that the intermittent generators produce power whenever they can, additionally increasing high variability of this type of power (Fogelberg \& Lazarczyk 2017). Electricity generation from wind sources is uncertain, implying unforeseen deviations from scheduled electricity programs. This greater range of variability also adds to the difficulty of forecasting output on the day-ahead timescale (Pérez-Arriaga \& Batlle 2012).

In previous years, these evident drawbacks significantly reduced the pace of implementation of these resources to existing energy systems. One solution to the latter problems would be increasing the power capacity of plants (and thus energy production) during periods of lower accessibility of a source. However, this may lead to significant power surpluses at times of high potential. Another way is the utilization of energy storage, which not only allows excess energy to be accumulated, 
but also its use at a suitable time and in appropriate amounts (Mauritzen 2013).

The abundance of excess energy produced in some power plants resulted in employment of ideas of converting the surplus power to another carriers, that can be utilized for various purposes. This energy shift is referred as "sector coupling" and is a promising solution to solve the problem of intermittency and excess power in the RES sector (Morris \& Pehnt 2014). One of the sectors that is linked to the power grid is district heating.

In this study, the utilization of energy surpluses, generated by wind power plants was examined. Basing on meteorological data from the area of Westfjords (Iceland), the potential of this energy source was examined. The existing local district heating systems in the following cities: Ísafjörður, Patreksfjörður, Bolungarvík and Flateyri, were proposed as power receivers. The projected system combines wind turbines, district network and heat tanks to ensure stable output, leveling hourly disturbances in power generation.

The following paper is the result of a project carried out in Iceland in 2018. Thanks to European Union grants from the Erasmus+ programme, Mr. Kamil Mathews - a student from the Faculty of Geology, Geophysics and Environmental Protection at AGH UST - was able to participate in a student exchange. The University of Iceland acted as the hosting partner, enabling him to perform a project at the Keilir Institute of Technology in Reykjanesbaer. The study objectives included proving the significant wind power potential in the Westfjords area and indicating the possibility of increasing the use of wind turbines in Iceland by examining the feasibility of the aforementioned system. The following project is a continuation of studies conducted in this part of Iceland by Polish students (Sowiżdżał \& Drabik 2016).

\section{BACKGROUND INFORMATION}

\section{Geographical review}

Iceland is a European country placed on an island of the same name in the North Atlantic. It is situated on the edge of two tectonic plates: Eurasian and North American. The boundary between them is divergent, which means they are drifting apart at a rate of $2 \mathrm{~cm}$ per year (Björnsson et al. 2010). Therefore, this region is characterised by high tectonic activity manifested by earthquakes and vulcanism. The island itself started forming about 16 million years ago (Steinthorsson 2002), which means that it can be classified as a geologically young land.

The area of the country is $103,000 \mathrm{~km}^{2}$ (Statistics Iceland, on-line). Approximately $11 \%$ of this is covered by glaciers. The island is mainly a tableland with an average elevation of $557 \mathrm{~m}$ above sea level. In general, lowland areas are situated close to the coastline, whereas the highlands form the interior of the country (Ólafsson et al. 2014). High average elevation as well as proximity to the sea are the main factors contributing to steady and strong winds. The wind speeds are in general higher in the highlands and lower in the lowlands, yet in some cases the topography may reverse these trends, e.g. the presence of large ice caps leads to the generation of katabatic wind in the area of Vatnajökull. Iceland has an abundant supply of water. According to the data from 2014 (World Bank, on-line) the total renewable water resources per capita per year were assessed as $519,265 \mathrm{~m}^{3}$ ranking it as the water wealthiest country in the world. The average precipitation ranges between $500 \mathrm{~mm}$ in the north of the country and $2000 \mathrm{~mm}$ in the southern part). Iceland has the highest average annual precipitation in Europe (1940 mm), compared to other countries such as the United Kingdom $(1220 \mathrm{~mm})$, Norway $(1410 \mathrm{~mm})$ or Sweden $(624 \mathrm{~mm})$.

\section{Energy production in Iceland}

Iceland is best known for its vast geothermal potential. According to data provided by the National Energy Authority (Orkustofnun Data Repository OS-2018-T006-01 2018) in 2017 almost all the electricity $(99.99 \%)$ was produced by renewable energy sources (mainly hydro power plants). Other statistics (Orkustofnun Data Repository OS2018-T010-01 2018) provide information on space heating, where the key source $(89.2 \%)$ was geothermal energy followed by electricity and a small amount of oil. This is a result of wide access to geothermal heat in the most populated areas in Iceland. Some locations however are either remote from district heating systems or lack geothermal 


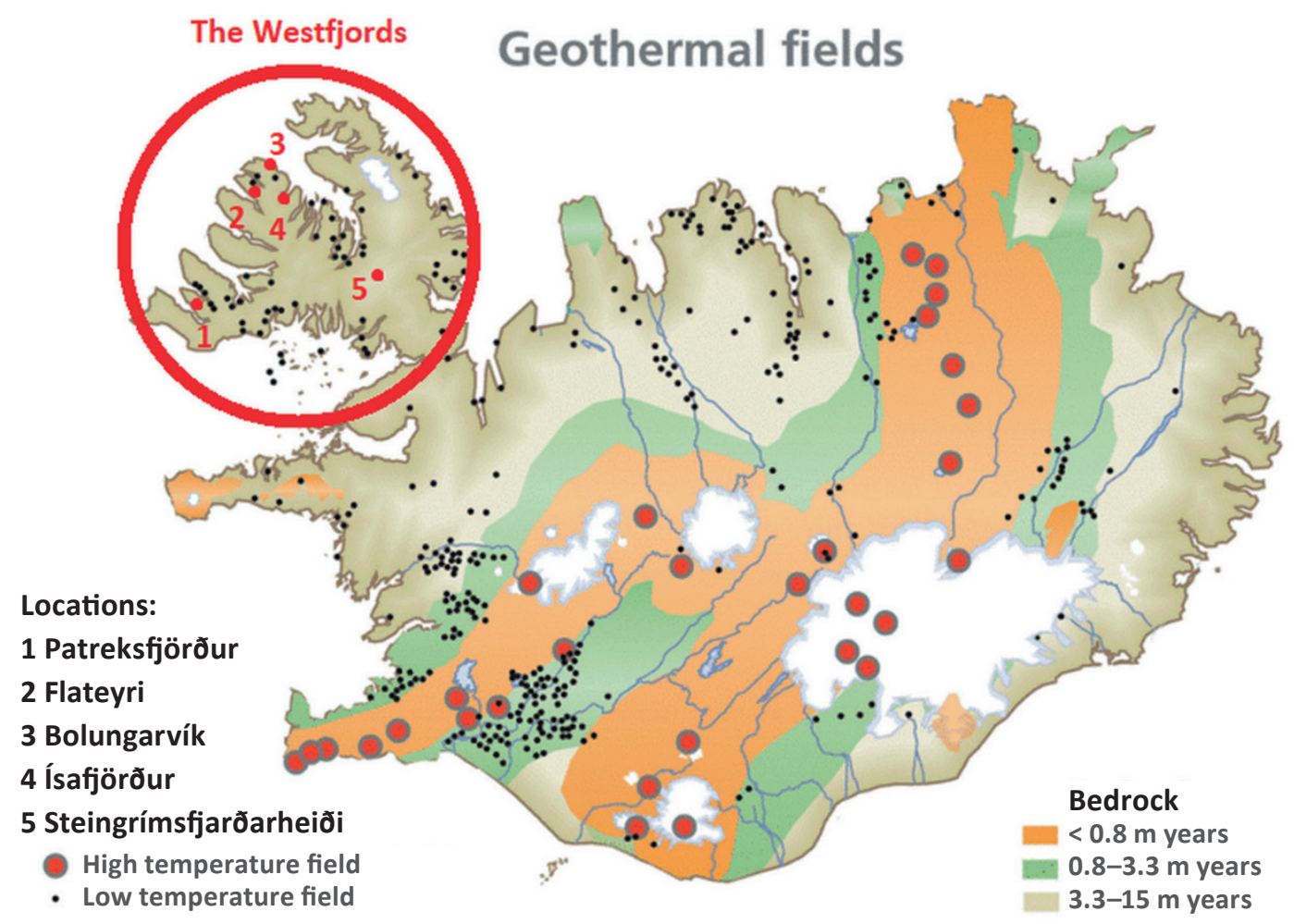

Fig. 1. Volcanic zones and geothermal areas in Iceland (with the selected locations in the Westfjords) (Björnsson et al. 2010)

resources. Hence further increase in geothermal usage is unlikely (Björnsson et al. 2010). Those places need to be supplied using other forms of energy. Westfjords is an example of such area. It is distant from the main populated areas, as well as geothermal fields, as presented in Figure 1. Only a few district heating systems exist in this region, in the main population centres, where electricity is a primary source of heat energy.

Although in 2017 almost the entire electricity production in Iceland came from RES, renewables constituted $81.2 \%$ of total primary energy use (Orkustofnun Data Repository OS-2018-T009-01 2018). The remaining part was provided by oil or coal, utilised mainly in transportation and heavy industry. The share of renewables in primary energy use has been increasing in recent years, mainly owing to use of geothermal energy and hydropower. The current share of geothermal energy in total primary energy use is approximately $61 \%$ (which corresponds to $150 \mathrm{PJ}$ ) while hydropower is about of $20 \%$ (50 PJ).

\section{Wind power potential in Iceland}

Iceland has a favourable climate for wind power (Nawri et al. 2014). As stated in a report issued by the Icelandic Meteorological Office (Nawri et al. 2013) the wind potential in Iceland can be ranked at the highest wind power class in Western Europe. At a height of $50 \mathrm{~m}$ above ground level the average annual wind power density is equal to 250 $\mathrm{W} / \mathrm{m}^{2}$ over sheltered terrain, $700 \mathrm{~W} / \mathrm{m}^{2}$ along the open coast and $1800 \mathrm{~W} / \mathrm{m}^{2}$ on the tops of hills and ridges. These values are achieved in the windiest regions of Europe, such as Scotland and Denmark. Nonetheless, apart from small scale solutions used for individual needs, presently there are only 4 grid-scale wind turbines in operation (two in Búrfell - Hafið and another two in Pykkvibær) in the south-west part of the country (Orkustofnun Data Repository OS-2018-T006-01, 2018). Wind power is still in its experimental stage in Iceland and the Master Plan does not specify the potential of wind power (Duenasa et al. 2018). However, it is 
also claimed that since the results of operating project have exceeded expectations, a further increase in wind power utilisation is predicted. The main cause for a such low utilisation rate is currently the relatively low LCOE for geothermal and hydropower projects in Iceland, which have held an economic advantage over wind power to date (Olafsson 2016). According to the MIT Energy Initiative (Pérez-Arriaga 2017) the average cost of electricity for wind power projects is close to $35 \mathrm{USD} / \mathrm{MWh}$, whereas a federation of energy and utility companies in Iceland presents a LCOE of hydropower projects ranging from 22.5 to $60.5 \mathrm{USD} / \mathrm{MWh}$ and of geothermal plants: 28.9-57.3 USD/MWh.

\section{Wind power potential in the Westfjords}

The region of the Westfjords may be considered as both maritime and mountainous. These two types of terrain are often closely linked to steady wind conditions. As the wind power sector in Iceland has - so far - marginal importance, no wind turbines are located in this area (Nawri et al. 2014). Nevertheless, the potential of this source of energy is predicted to be substantial and hence it was examined in this research.

\section{METHODOLOGY OF WIND TURBINES \\ IMPLEMENTATION PROJECT}

\section{Wind power}

Data regarding district heating systems as well as weather measurements were collected for the needs of this study. The analysis was based also on data contained in the countrywide Windatlas. The weather observation stations located close to municipalities with district heating systems, Bolungarvík, Patreksfjörður, Flateyri, Ísafjörður, were used as a primary source of data. In addition, one station (Steingrímsfjarðarheiði) at a location of higher altitude (and hence predictably higher wind potential) was chosen in order to compare the data.

As a first step, preliminary estimates of energy generation from a single wind turbine were assessed. Having regard to the harsh climatic conditions, Vestas V126-3.45 MW was the chosen model, since it is equipped with a de-icing system. The tower height was determined at $117 \mathrm{~m}$ according to the IEC 61400 standard (International Electrotechnical Commission 2014) and manufacturer's instructions.

The wind measurement data were extrapolated to the designated height using the Log Law presented in (Manwell et al. 2011):

$$
\frac{U(z)}{U\left(z_{r}\right)}=\frac{\ln \left(\frac{z}{z_{0}}\right)}{\ln \left(\frac{z_{r}}{z_{0}}\right)}
$$

Equation (1) - Log Law - allows to extrapolate the wind speed to a certain height, where:

$U(z)$ - wind speed at height $z$,

$U\left(z_{r}\right)$ - reference wind speed at height $z_{r}$,

$z$ - height above ground level (assumed as $117.0 \mathrm{~m}$ ),

$z_{r}$ - reference height above ground level (measurement height of $10.0 \mathrm{~m}$ or $6.0 \mathrm{~m}$ ),

$z_{0}$ - roughness length (assumed as $0.030 \mathrm{~m}$ ).

Subsequently wind data was extracted from the Windatlas, which provided information on a modelled wind climate for 12,462 grid points over Iceland. In order to compare the modelled data with the actual measurement data provided by the Icelandic Meteorological Office, points closest to the actual weather stations locations were picked.

Wind speed frequency may be expressed by Weibull distribution (Seal \& Sherry 2016):

$F(x, k, A)=1-e^{-(x / A)^{k}}$

Equation (2) depicts cumulative distribution function for Weibull distribution, where:

$$
\begin{aligned}
& x \text { - variable, } \\
& k \text { - shape parameter, } \\
& A \text { - scale parameter. }
\end{aligned}
$$

In order to assess the technical wind power potential, the distributions were calculated for every direction and summed into a single distribution. Then they were combined with a power curve of selected wind turbine. As a result, wind power cumulative distribution and total yearly production were obtained. 
The above calculations were performed for every location (both for measurements and modelled data), whilst two points were assigned to the city of Ísafjörður (one closer to the city centre, the other on top of the surrounding hills). The distribution parameters were assumed for a height of $100 \mathrm{~m}$ and surface roughness of $0.030 \mathrm{~m}$.

\section{District heating}

The second part of this project was to define the specifics of a District Heating System (DHS) as an energy receiver. The data regarding heat usage in DH systems in the Westfjords were provided by the Westfjord Power Company. After basic data cleansing, the hourly time-series of DHS energy demand in Ísafjörður and the linear correlation between heat demand and air temperature were plotted.

\section{Wind turbines and district heating}

The first and most important step in sizing the system is to assess the amount of energy produced and used within it.

At this point two approaches are available:

1) to locate wind turbines (WT) in the vicinity of district heating systems (DHS) - assumed for Bolungarvík, Flateyri, Îsafjörður and Patreksfjörður;

2) to locate wind turbines (WT) in more favourable areas in terms of wind conditions and transmit power to DHS - assumed for Ísafjörður; this city is located on the seaside, in a valley; however, within $5 \mathrm{~km}$ there are mountains with flat tops, whose elevation exceeds $700 \mathrm{~m}$; therefore, the wind measurement data from Steingrímsfjarðarheiði have been extrapolated to create this new point called "Ísafjörður (hill top)".

The number of wind turbines was calculated by matching the generation from a single wind turbine with heat demand so that the total production is equal to or higher than the usage for every location. The results were presented in Table 1.

In the second step, the correlation between energy production and usage throughout the whole year was assessed. This will suggest whether the supply can meet demand for most of the time. The linear Pearson correlation coefficients were calculated for hourly, daily, weekly, fortnightly, monthly and seasonal data values together with respective parameters of statistical significance.

The proposed system schematic is presented in Figure 2. Base load from Wind Turbines (WT) is utilised to preheat water in Thermal Energy Storage (TES), which levels the short-term unstable output from WT. Then water is passed to an electric boiler, heated up (if needed), and distributed to recipients by the existing District Heating Network (DHN). Cold water returns to the TES. If the demand is lower than power supply, excess energy from the WTs is exported to the power grid. If the WTs are not generating enough power for the $\mathrm{DHN}$, energy is imported from the grid.

Table 1

Number of wind turbines satisfying the amount of heat demand in every location

\begin{tabular}{|l|c|c|c|c|}
\hline \multicolumn{1}{|c|}{ City name } & $\begin{array}{c}\text { District heating } \\
\text { demand } \\
\text { [GWh/year] }\end{array}$ & $\begin{array}{c}\text { District heating } \\
\text { location }\end{array}$ & $\begin{array}{c}\text { Single wind turbine } \\
\text { energy production } \\
\text { [GWh/year] }\end{array}$ & $\begin{array}{c}\text { Number } \\
\text { of wind turbines } \\
\text { satisfying demand }\end{array}$ \\
\hline Bolungarvík & 12.7 & Bolungarvík & 10.4 & 2 \\
\hline Flateyri & 5.5 & Flateyri & 10.9 & 2 \\
\hline Patreksförður & 14.2 & Patreksförður & 9.5 & 5 \\
\hline \multirow{2}{*}{ Ísafjörður } & 45.5 & Ísafjörður (city) & 9.2 & 3 \\
\cline { 2 - 5 } & & Ísafjörður (hill top) & 17.3 & 2 \\
\hline
\end{tabular}




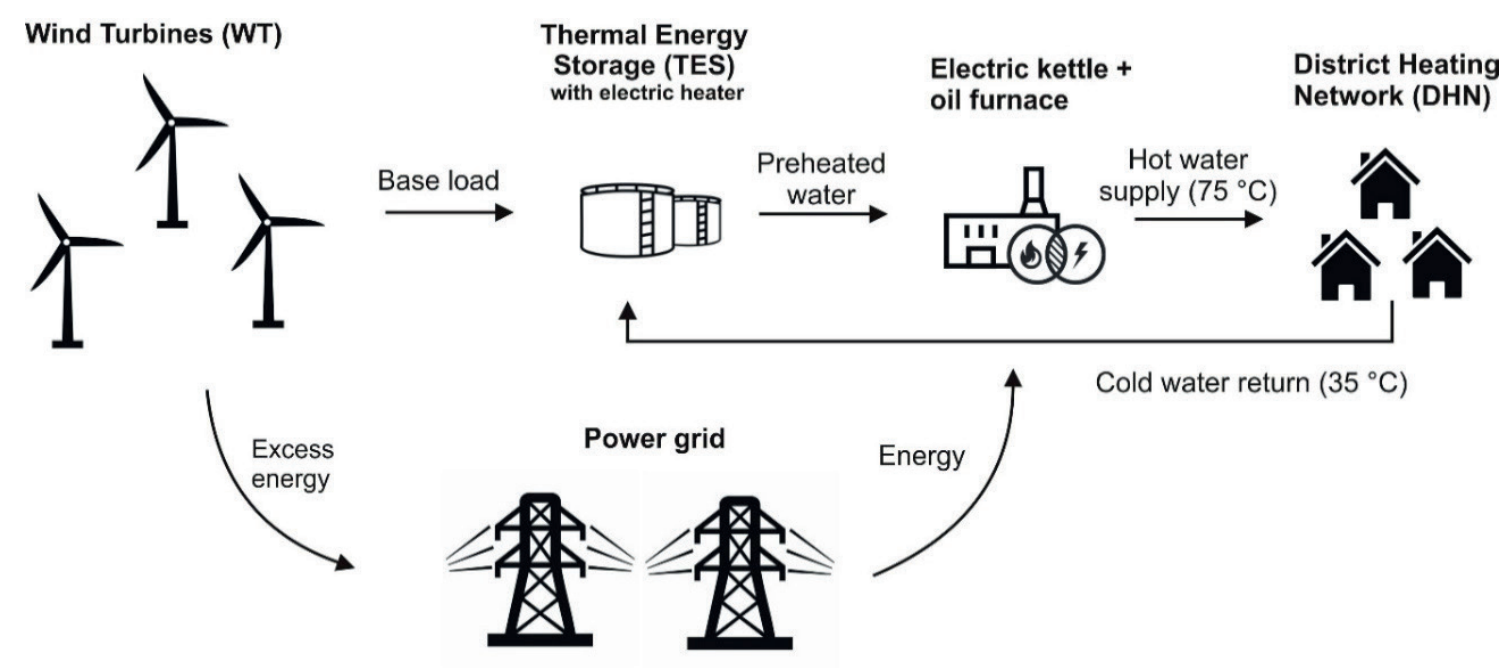

Fig. 2. Scheme of the proposed system

Based on hourly data of energy generation from WTs and heat usage in DHS for selected cities in the Westffords region, the energy flows in hypothetical systems were calculated. Every hour the production could be higher, equal or lower than demand. In the first case the energy surpluses from WT generation are exported to the grid, in the second - there is an equilibrium in the system, and in the final case, the energy is imported to the DHS from the grid. This approach depicts how much energy is used directly by the system and how much is either imported or exported to the grid. The percentage of wind power utilised in the DHS is recognised as a rate for self-sufficiency, as it indicates how much energy was provided by WTs instead of by the grid.

\section{RESULTS OF WIND TURBINES IMPLEMENTATION PROJECT}

\section{Wind power}

In the first step, monthly wind speed data for the last 5-year period (2013-2017), extrapolated to a height of $117 \mathrm{~m}$ above ground level, were examined for every selected location. As a result, 5 -year averages curves were plotted together in a summary chart Figure 3. Even superficial analysis shows significant seasonality in the data, i.e. wind speed varies throughout the year. The highest wind speeds were observed in winter, whereas the lowest were noted in summer. This pattern is recurrent for each the selected locations in the Westfjords region. Steingrímsfjarðarheiði is characterized by the highest wind potential, mainly due to the higher elevation of this weather station.

The results of single wind turbine power calculations for the selected locations (both for the Wind atlas model data and 2017 real wind measurement data) are presented in Figure 4, which shows the high potential of wind power in the Westffords. Total energy production and capacity factors are significantly higher for the Windatlas data, than for real measurement data.

This may be due to:

- lower wind speed in 2017;

- the sparse data resolution of the Windatlas (the grid points spacing equals to $3 \mathrm{~km}$ );

- boundary-layer model utilised in the Windatlas; since it does not include turbulent air flow, the wind speed may sometimes be overestimated, especially for terrains of variable morphology, such as the Westfjords.

In addition, capacity factors were marked for every data point and compared with average capacity factors of onshore and offshore wind turbines in the European Union. Almost every hypothetical wind turbine performance may exceed the productivity of typical generators in the EU.

The validity of the results might be confirmed by the capacity factor of the wind power plant operating in Hafið (south Iceland), which is $40 \%$. 


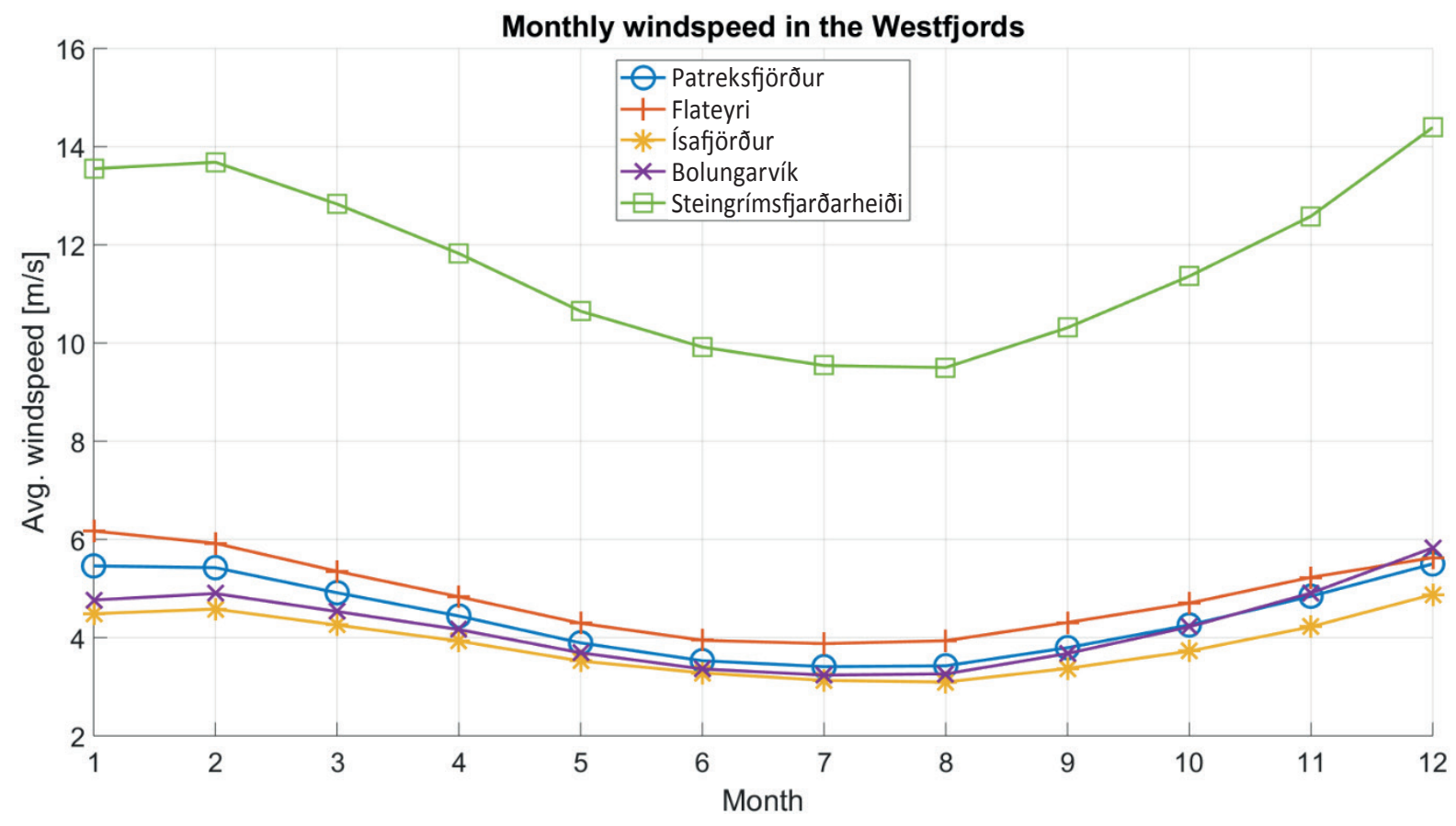

Fig. 3. Monthly wind speeds at $117 \mathrm{~m}$ above ground level

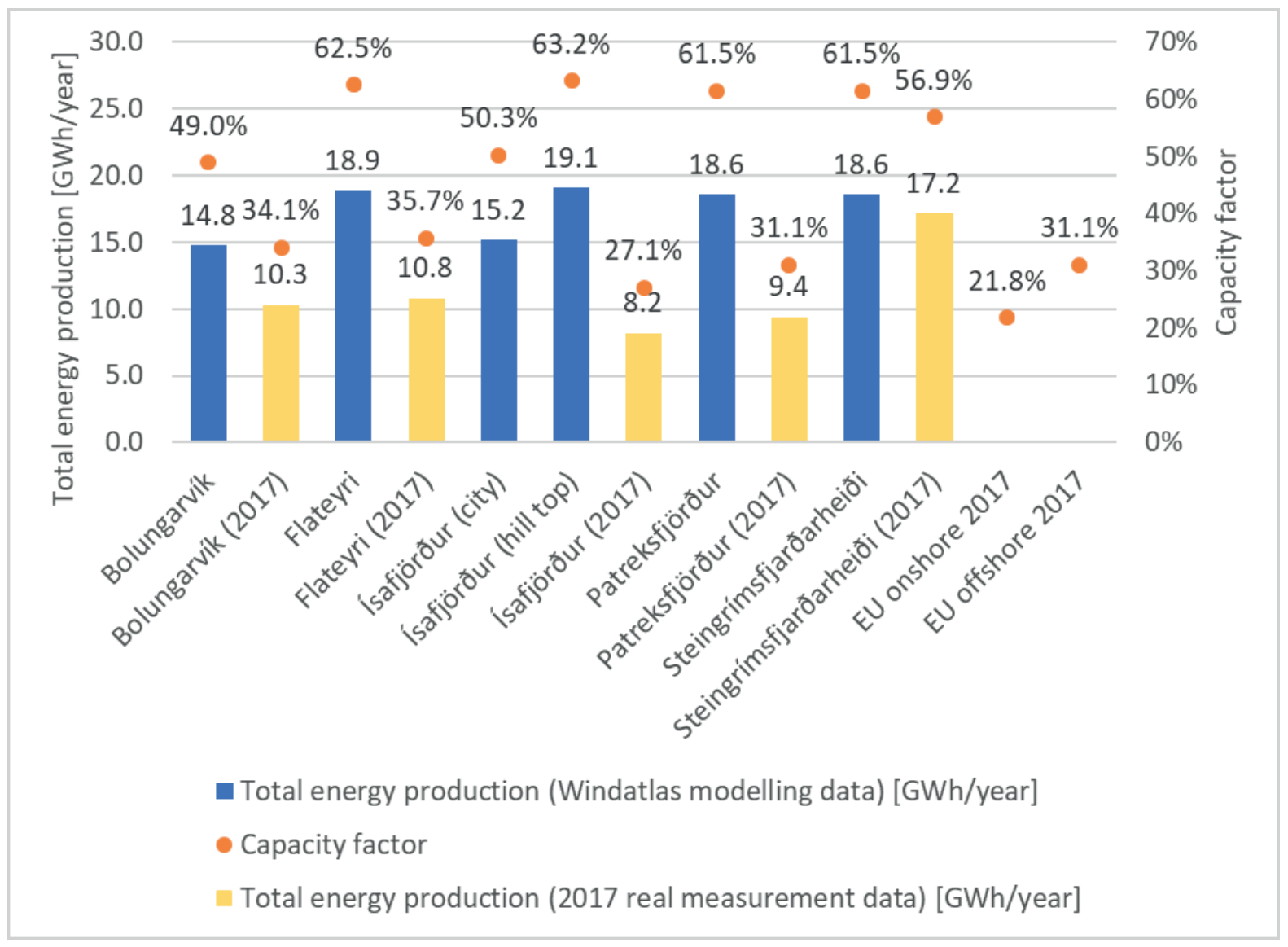

Fig. 4. Estimated energy production of wind turbines in the Westfjords and capacity factors in comparison with European Union onshore and offshore capacity factors in 2017 


\section{District heating}

Figure 5 depicts hourly energy demand in Ísafjörður. Energy usage is constant throughout the day, with a reduction at night between 22:00 and 7:00. The highest demand for heat occurs in winter (above $8000 \mathrm{kWh} /$ hour - yellow lines close to the edges), whilst it is lowest in summer (less than $3000 \mathrm{kWh}$ /hour - blue areas in the centre).
For this reason, a high reverse correlation (correlation coefficient: -0.89 ) was observed between DHS energy demand and air temperature, as showed in Figure 6. The higher the ambient temperature the lower is the heat usage. This pattern is recurrent for every DHS in the Westfjords, as the hourly data of heat usage are well correlated between the cities (correlation coefficients are above 0.85).

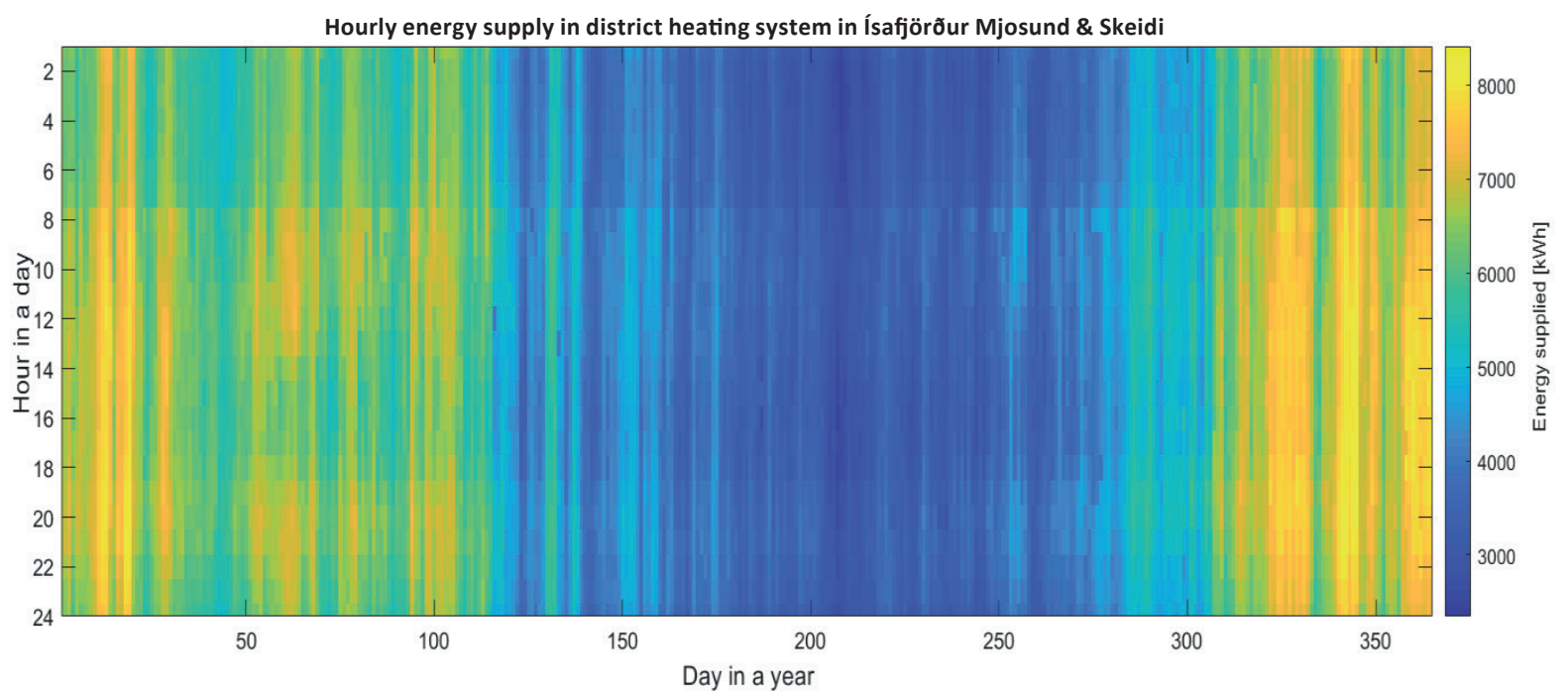

Fig. 5. Ísafjörður District Heating hourly energy demand in 2017

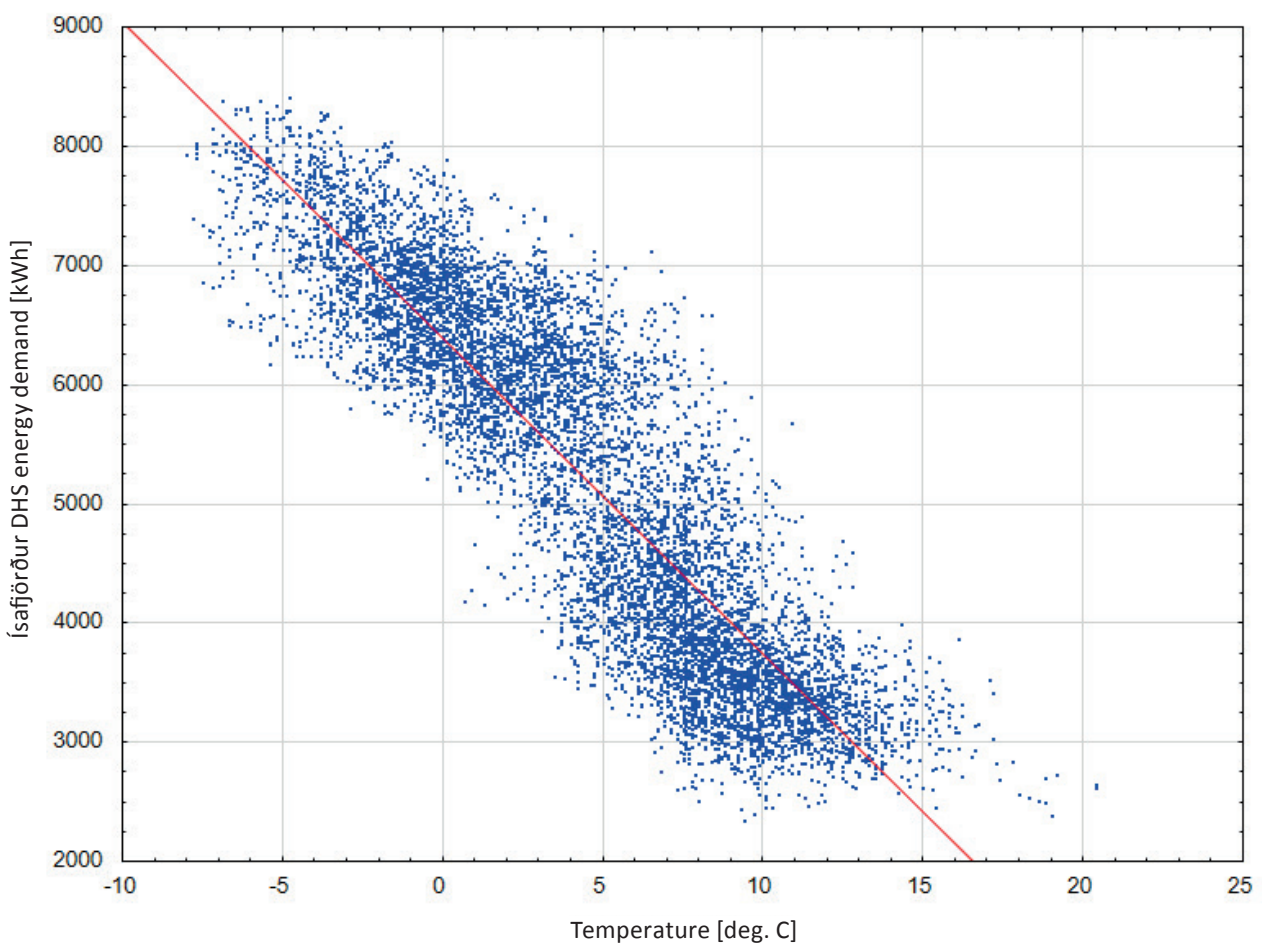

Fig. 6. Correlation between heat demand in Ísafjörður DHS and air temperature 


\section{Wind turbines and district heating}

In Figure 7 the correlation coefficients were presented in respective time-period with division into two cases:

1) wind turbines (WT) are located in the vicinity of district heating systems (DHS) in Bolungarvík, Flateyri, Ísafjörður and Patreksfjörður;

2) wind turbines (WT) are located in high wind speed areas (Îsafjörður - hill top), whereas the district heating system (DHS) is in Ísafjörður; These two approaches brought different results:

1) in longer time periods energy generation and usage are correlated; therefore, themain focusshould be placed on short-term energy storage, which can align the hourly difference between wind turbine energy production and DHS demand;

2) in case of distant separation between the generation and usage units, the correlation drops, and the p-value increases, so that the coefficients are no longer statistically significant.
In Figure 8 cities are presented in terms of DHS heat demand, WT energy production and their common part (auto-consumption). The number of WTs is proposed in Table 1.

The energy flows in hypothetical systems are illustrated. On average $60 \%$ of heating demand could be provided by wind turbines, whereas the remaining $40 \%$ would have to be supplied by the grid. At this point it is also worth noting that for the instance of Ísafjörður, 3 WT located on the hill top generate similar amounts of energy as 5 WT close to the city centre.

In addition, better wind conditions provide a more stable power output, which is more similar to the quite constant heat demand throughout the year. By that means the auto-consumption (energy used directly in the system vs. total energy produced) in the system increased from $51 \%$ (Îsafjörður - city) to almost 60\% (Îsafjörður hill top).

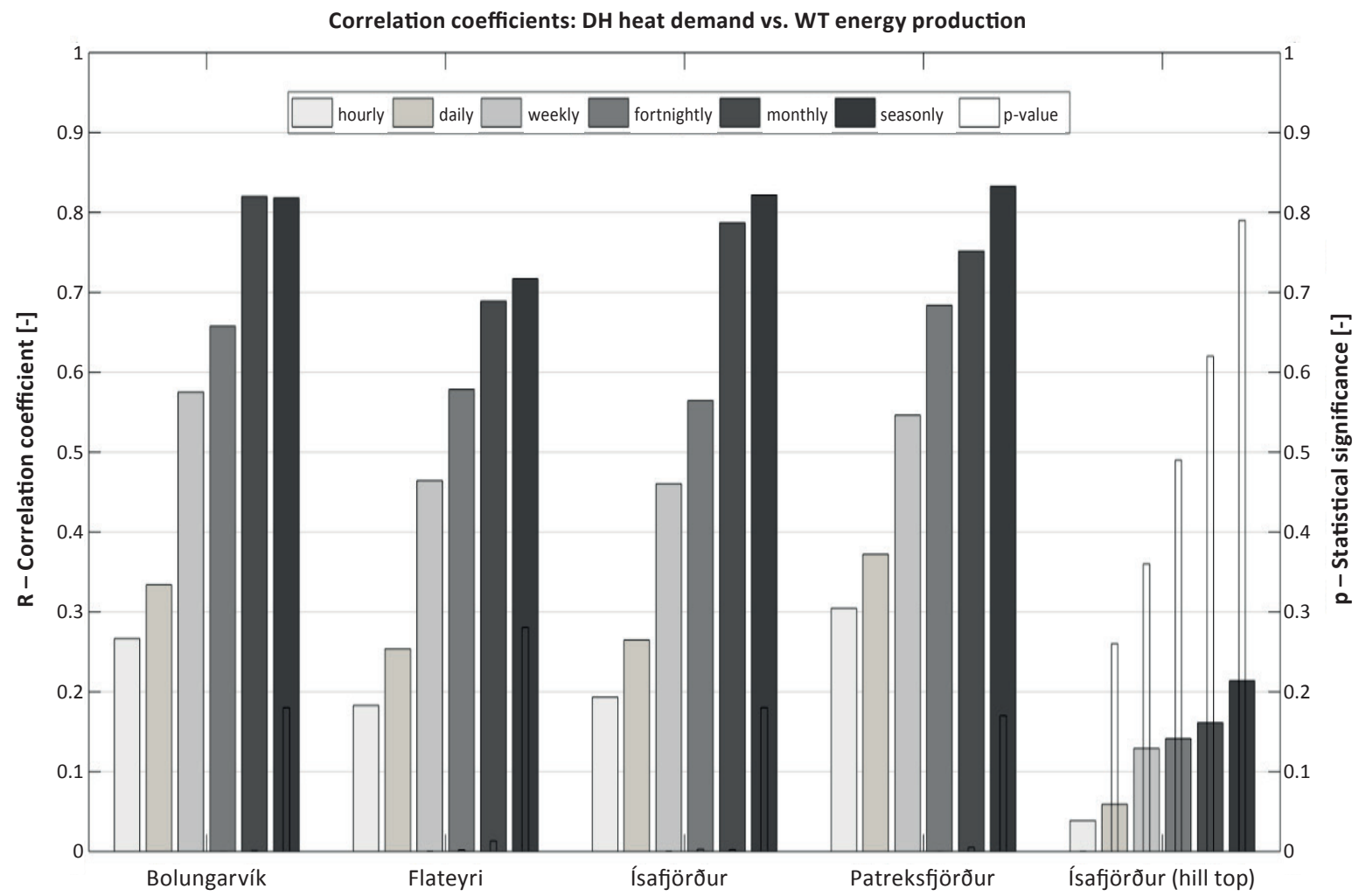

Fig. 7. Correlation coefficients between DH heat demand and WT energy production for selected locations in the Westfjords with corresponding values of statistical significance 


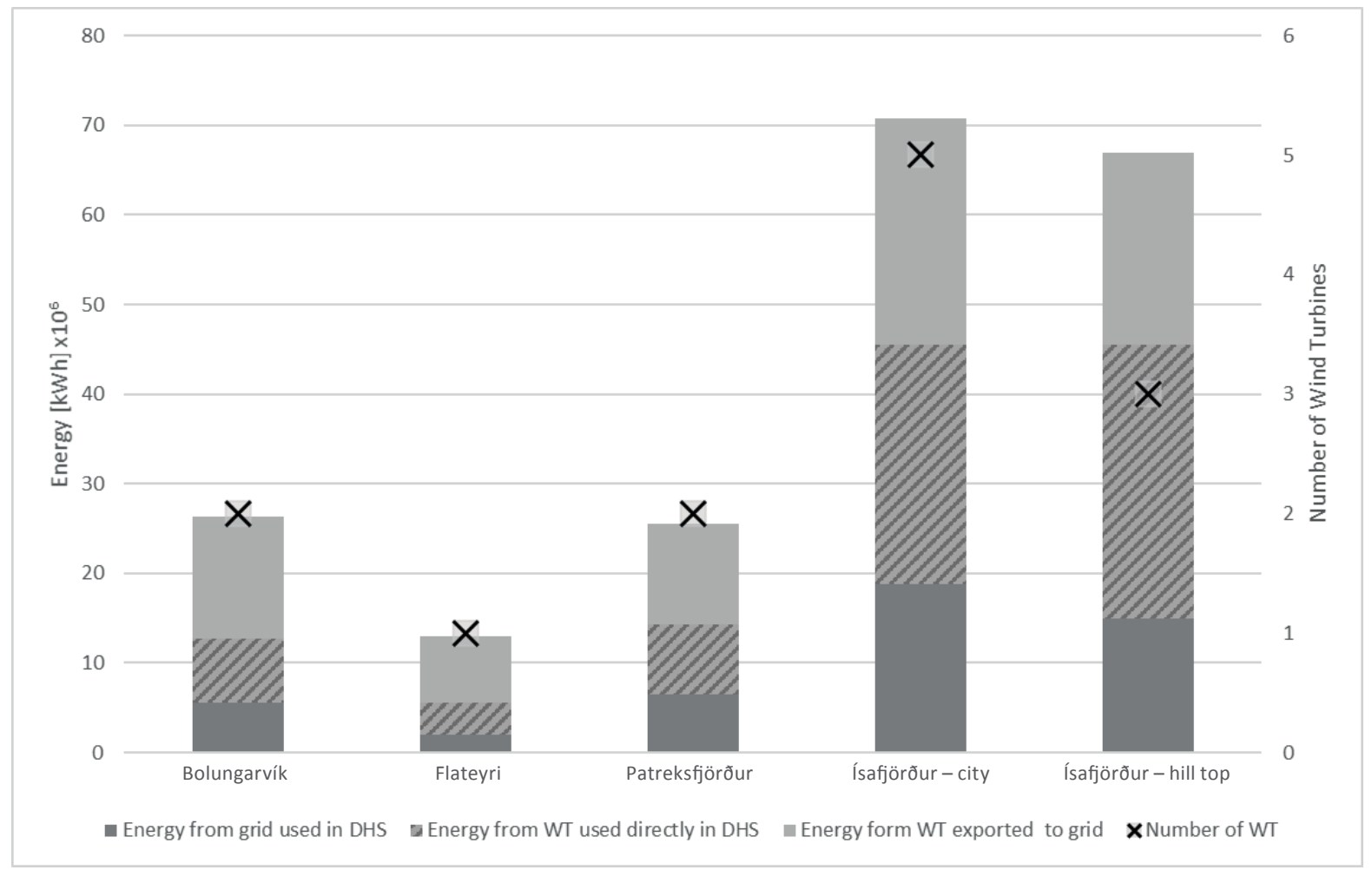

Fig. 8. Energy flows in DHS and number of proposed WT in the Westfjords

\section{DISCUSSION}

In the study presented here, wind power was proposed as an alternative energy source for district heating networks in the Westfjords. This approach is relatively innovative, since to date there is only a small amount of research dealing with the use of wind energy for the needs of district heating systems.

The potential of wind power in the Westfjords was investigated, on the basis of weather measurements and wind model data from the Windatlas. It was proved that this region is characterised by steady high-speed winds. These preferential conditions are prominent, and the hypothetical production of wind turbines often exceeds the average generation of European Union offshore wind power plants. The high elevated plateaus are considered to be especially suitable areas for the location of wind turbines.

The investigation of district heating networks indicated relatively stable demand throughout the day and year, correlated reversely with ambient temperature. High correlation was also noticed between the DH demand and WT generation when they were located close to each other, particularly for long time periods (fortnight, month). However, it was demonstrated that this correlation does not necessarily provide a high rate of matching of energy production and usage. In fact, stable output throughout the year, typical for places with better wind conditions, was proposed as a better indicator of this fit.

Despite the high potential of wind power, so far this source of energy is underestimated in Iceland. The reason for this fact could be its intermittency. The results of this study demonstrate that considering the appropriate coupling of wind turbines and district heating networks can be justified and that this might pose a solution to the given problem.

\section{LIMITATIONS}

As the issue of sector coupling considered in this study is complex, it is recommended that further studies in this area are carried out. First and foremost, deeper analysis of technical feasibility 
ought to be performed. It should cover the issues of possible locations in terms of grid connection and designing partially off-grid systems including control and measurement equipment. Careful attention must be paid to the selection of system components, as they have to be resistant to harsh local weather conditions (e.g. a wind turbine icing prevention system). Secondly, the economic analysis should address project profitability in at least a few variants and locations, regarding all the risks and benefits of this investment. In addition, further data collection would be needed to determine long-term trends and forecasts for the decades to come, since the expected system lifetime ranges from 20 to 30 years. Moreover, utilisation of more advanced, specialist software is recommended in order to execute accurate performance analysis. Last but not least, an environmental assessment should precede any relevant decision, with an attempt to reduce the probable negative impact to the highest possible extent.

\section{CONCLUSIONS}

The aim of this research was to assess the feasibility of the installation of wind turbines for use in existing district heating networks in the Westfjords, Iceland. The aforementioned results clearly indicate that there are strong arguments supporting this solution. Wind power has a significant potential in the Westfjords. The calculated performance of wind turbines was based both on modelled and real measurement data. Depending on locations, the capacity factor of these power plants ranged from $27.1 \%$ to $59.1 \%$ mostly exceeding the productivity of EU off-shore wind farms (average capacity factor $31.1 \%$ ). On the other hand, district heating networks were demonstrated as large and steady power recipients, whose demand depends predominately on ambient temperature. The analysis also underlined the importance of wind turbine location. In the long term (monthly calculations), a high correlation (average coefficient 0.76) was found between energy production and usage for wind turbines located close to the city. Despite that, locating even fewer turbines in steady wind conditions proved to satisfy more heat demand with a similar amount of energy produced. It was argued that without long-term storage of energy, nearly $60 \%$ of power demand could be supplied by wind turbines. Further research in this topic may demonstrate the benefits of implementing energy storage systems. In conclusion, properly located wind turbines might be a promising source of energy for district heating networks in the Westfjords.

Special thanks go to Ms. Krista Hannesdóttir from Keilir Institute of Technology in Reykjanesbaer for her engagement at every stage and invaluable contribution to this project. The paper prepared under statutory research grant no. 11.11.140.031.

\section{REFERENCES}

Björnsson S. (ed.), Gudmundsdottir D. \& Ketilsson J., 2010. Geothermal Development and Research in Iceland. Orkustofnun.

Duenasa P., Ramos A., Ahumadaa K.T., Olmosb L., Rivierb M. \& Pérez-Arriaga J.I., 2018. Security of supply in a carbon-free electric power system: The case of Iceland. Applied Energy, 212, 443-454.

Ellabban O., Abu-Rub H. \& Blaabjerg F., 2014. Renewable energy resources: Current status, future prospects and their enabling technology. Renewable and Sustainable Energy Reviews, 39, 748-764.

Fogelberg S. \& Lazarczyk E., 2017. Wind power volatility and its impact on production failures in the Nordic electricity market. Renewable Energy, 105, C, 96-105.

International Electrotechnical Commission, 2014. IEC 61400-1:2005/AMD1:2010. International Standard. Wind Energy Generation Systems.

Manwell J., McGowan J.G. \& Rogers A.L., 2011. Wind Energy Explained: Theory, Design and Application. $2^{\text {nd }}$ ed. John Wiley \& Sons.

Mauritzen J., 2013. Dead Battery? Wind Power, the Spot Market, and Hydropower Interaction in the Nordic Electricity Market. The Energy Journal, 34, 103-123.

Morris C. \& Pehnt M., 2014. Energy Transition: The German Energiewende. Heinrich Böll Stiftung.

Nawri N., Petersen G.N., Björnsson H. \& Jónasson K., 2013. The wind energy potential of Iceland. Veðurstofa Îslands. Report VÍ 2013-001, Icelandic Meteorological Office.

Nawri N., Petersen G.N., Björnsson H., Hahmann A.N., Jónasson K., Hasager Ch.B. \& Clausen N.E., 2014. The wind energy potential of Iceland. Renewable Energy, 69, 290-299.

Ólafsson F., Björnsson B.B. \& Porbergsson L., 2014. The Icelandic Economy. Current State, Recent Developments and Future Outlook. $17^{\text {th }}$ ed. Iceland Chamber of Commerce.

Ólafsson K.B., 2016. Levelized Cost of Energy (LCOE) og virkjunarkostir til umfjöllunar í 3. áfanga rammaáotlunar.

Orkustofnun Data Repository OS-2018-T006-01, 2018. Installed electrical capacity and electricity production in Icelandic power stations 2017.

Orkustofnun Data Repository OS-2018-T009-01, 2018. Primary Energy Use in Iceland 1940-2017.

Orkustofnun Data Repository OS-2018-T010-01, 2018. Proportion of energy source in space heating based on heated space. 
Pérez-Arriaga I., 2017. Electricity Security of Supply in Iceland (Part II: Economic Assesment). MIT Energy Initiative.

Pérez-Arriaga I. \& Batlle C., 2012. Impacts of Intermittent Renewables on Electricity Generation System Operation. Economics of Energy \& Environmental Policy, 1, 2, 3-18.

Rahbar K., Xu J. \& Zhang R., 2015. Real-time energy storage management for renewable integration in microgrid: An off-line optimization approach. IEEE Transactions on Smart Grid, 6 (1), 124-134.

Seal C.K. \& Sherry A.H., 2016. Weibull distribution of brittle failures in the transition region. Procedia Structural Integrity, 2, 1668-1675.

Shen Z. \& Ritter M., 2016. Forecasting volatility of wind power production. Applied Energy, 176, 295-308.
Sowiżdżał A. \& Drabik A., 2016. Petrogeothermal energy resources within low-temperature areas of Iceland. Geology, Geophysics \& Environment, 42, 4, 391-401.

Statistics Iceland, [on-line:] http://px.hagstofa.is [access: 30.12.2018].

Steinthorsson S., 2002. Catalog of Active Volcanoes of the World - Iceland [unpublished manuscript].

The World Bank, Renewable internal freshwater resources per capita(cubicmeters). [on-line] https://data.worldbank.org/ indicator/er.h2o.intr.pc [access: 23.07.2018].

Turkenburg W.C. et al., 2000. Renewable energy technologies. [in:] World Energy Assessment: Energy and the Challenge of Sustainability, UNDP/UNDESA/WEC, New York, 219-267. 